\title{
INVERSION OF MARKETING STRATEGIES IN CULTURAL AND LEISURE ACTIVITIES
}

\author{
Borodai V.A. (Russian Federation) Email: Borodai327@scientifictext.ru
}

\author{
Borodai Vladimir Aleksandrovich - Doctor of Social Sciences (DSSc), Associate Professor, \\ DEPARTMENT OF ECONOMICS, \\ Professor, \\ DEPARTMENT OF SERVICE, TOURISM AND HOSPITALITY INDUSTRY \\ DON STATE TECHNICAL UNIVERSITY, ROSTOV-ON-DON
}

\begin{abstract}
: considerations of the consumer about the preferred life that generate the needs for cultural and recreational products (services). The need for a cultural and recreational product is not only a need for it, but also a search for certain benefits. That's why marketing focuses not on marketing a product (service), but on marketing the customer's benefits. It is shown that the activation of hidden and passive needs is part of the necessary measures to enter any new product or service on the market. Conjugated with her difficulties can affect the process of distribution of the novelty. For forecasting sales, key is also an assessment of the ability to uncover hidden and passive needs.
\end{abstract}

Keywords: cultural and recreational services, need, communication, barriers, innovation, inversion.

\section{ИНВЕРСИЯ МАРКЕТИНГОВЫХ СТРАТЕГИЙ В КУЛЬТУРНО-ДОСУГОВОЙ ДЕЯТЕЛЬНОСТИ Бородай В.А. (Российская Федерация)}

\author{
Бородай Владимир Александрович - доктор сочиологических наук, дочент, \\ кафедра экономики, \\ профессор, \\ кафедра сервиса, туризма и индустрии гостеприимства, \\ Донской государственный технический университет, г. Ростов-на-Дону
}

\begin{abstract}
Аннотация: рассматриваются представления потребителя о предпочтительной жизни, которые порождают потребности в культурно-досуговых продуктах (услугах). Потребность в культурнодосуговом продукте - это не только нужда в нем, но и поиск определенных выгод. Вот почему маркетинг фокусируется не на маркетинге продукта (услуги), а на маркетинге выгоды клиента. Показано, что активизачия скрытых и пассивных потребностей является частью необходимых мероприятий вступления на рынок любого нового продукта или услуги. Сопряженнье с ней трудности могут повлиять на прочесс распространения новинки. Для прогнозирования продаж ключевой является также оценка способности раскрыть скрытые и пассивные потребности.
\end{abstract}

Ключевые слова: культурно-досуговые услуги, потребность, коммуникация, барьеры, инновация, инверсия.

One of the most promising areas of business development is socio-cultural activities. In other words, activities to provide cultural and leisure activities and services. At the same time, "... in order to withstand a market competition in a saturated market, the seller must know who his customers are, how often they buy and how much they spend in doing so" [1]. The presentation of the consumer about the preferred life creates a need for cultural and recreational products (services). But the needs stemming from the notion of a preferred life are usually only abstract needs. They conjure up a general type of sought satisfaction. Needs are always comparative, because, no matter what we require, the need is evaluated in comparison with displaced alternatives. The need, in contrast to desire, takes into account the feasibility of the conceived. Neither needs nor goals are supported if they can not be met and fulfilled. In addition, the need for a cultural-leisure product (service) is not only a need for it, but also a search for certain benefits. That's why marketing focuses not on product marketing (services), but on marketing benefits. The formation of an inversion approach to meet the needs based on the consumer's benefits creates innovative prospects for business development, the establishment of new corporate values that are broadcast to the external environment. In fact, in this way, the foundations of the branding of the company are being formed. "The employer brand should clearly reflect the cultural facts of a separate service organization. Solid, "right" companies have the courage not to homogenize their culture" [2]. Undoubtedly, the personnel of the service company should be aware and constantly feel the implicit nature of the relationship both between employees inside the company, and in communications with partners, consumers in the external environment. The qualitative nature of new marketing solutions in communications in the internal and external environment creates additional competitive advantages for the service company. 
The producer or provider of cultural and recreational services is rarely able to meet the needs completely. Nevertheless, it seeks to meet consumer expectations or surpass them. "Thus, the vector of formation of the image component of the service company is set, which can not but strengthen competitive positions in the market, it allows ensuring customer loyalty" [3]. Whenever serious expectations are not justified, frustration can prevent re-purchase. On the other hand, favorable reactions, caused by full justification of expectations, can help increase sales. Experiencing the need for an "X" means having a disposition to use, consume, or possess an "X". Having said that Jane wants to have "Mercedes", we are talking about her potential future of action, attributing to her some predisposition. Although the existence of a need can be accompanied by a strong sense of necessity, but usually it does not happen.

The need for a product (service) may be necessary, but not sufficient condition for its purchase. By itself, the need is not yet an excuse for action. There must also be relevant opinions. When the need is "passive", consumers are somewhat aware of the potential of the products, but, doubting its feasibility, refrain from acquiring it.

Hidden needs. Consumers may not realize, do not feel the need for a product, but they could feel it if they knew how it can improve their lives. In other words, the need for a product can be hidden. Consumers may not notice, misinterpret or have no idea of what constitutes persecution and the achievement of certain goals or needs. Advertising can give the product a new meaning and promote self-confidence of consumers, forcing them to imagine the pleasure of owning, using or consuming the product (service). "Relying on the two-factor social and psychological model, it's easy to make sure that the consumer always sees in the advertisement only what he wants to see. The initial advertising information is mediated, as it were, by the socio-cultural experience of the recipient, so the impact of advertising on economic behavior is not a direct one" [4].

Поэтому перед появлением активной потребности в продукте (услуге) человек сначала задумывается о его потенциале, воображает его. Так, мы можем знать о существовании продукта (услуги) и его функциях, но все же не знать достаточно о его выгодах, чтобы решиться на покупку.

Therefore, before the emergence of an active need for a product (service), a person first thinks about its potential, imagines it. So, we can know about the existence of the product (service) and its functions, but still not know enough about its benefits to decide on a purchase.

The latent need is activated, stimulating the perception of the commodity offer as desirable. The latent need for product $\mathrm{X}$ is more easily activated if the consumer already has a favorable attitude to the product category to which X. The "Sony" advertising will be able to more easily activate the latent need for the company's new video camera, since consumers identify it first as a "Sony" product, And secondly, as a product of Japanese electronics. Such a classification plus the novelty of the product would undoubtedly help the product to be recognized. This is largely facilitated by information technology. "Only thanks to the development of information technologies, the company gets the status of modern and relevant, can participate in global competitions and processes, have a unified data structure, channels of information distribution and is considered by corporations as a strategic partner" [5].

Identifying hidden needs requires skill. If consumers currently buy the product (service), then its consumption can be increased, providing its additional benefits. Perhaps, at first, consumers think simply about using the product (service) for its intended purpose, without thinking about its special properties and related benefits. And this could contribute to the formation of a synergetic component. "If we consider the organization as an integral system that is subject to the influence of external and internal factors and changing under their influence, it is possible to assume the existence of such a state of the system (company) at which the synergy effect appears" [6].

For example, potato consumption may rise sharply after nutritionists say that the potato does not contain "almost no fat, but it has many vitamins and minerals, which makes it a valuable source of food." Consumers, perceiving the product or brand as the carrier of function X (for example, baking soda is added to the dough), often do not have a clue about its fundamentally different functions (an open batch of baking soda placed in the fridge perfectly absorbs smells).

Consumers are often viewed as a concentration of needs that act as a filter, selecting products for future purchases. This ignores the fact that the consumer can be stimulated by the idea of the true possession, consumption or use of the product and the need for it.

The need can not be created, but can only be activated, since the underlying motivational predisposition to the preferred life already exists. The very reasoning can cause a need. Appealing to the imagination aims to change perceptions. The appeal to rationality is designed to provide a justification for the solution. The problem is to attract the attention of the consumer - after all, when the needs are hidden, he has no interest in the product.

This is easy if the product (service) is new, because the novelty evokes curiosity. Advertisers should take the problem of attracting attention with particular gravity. If advertising does not speak about what consumers are actively looking for, the latter are not located to contacts with such advertising. Very effective can be oral communication: rave reviews of friends about the product or watching the product "in the business" can significantly increase the potential of the product in our eyes. These actions speak of emotional competence in 
the relationship with consumers. "Indeed, the opportunity to be flexible, be able to communicate with people, motivate them to realize their potential to the fullest - this is all the result of a high level of emotional intelligence of the leader, leader" [7].

Activating the need links benefits to the notion of a good life. Generally speaking, one can appeal to values and not try to change them. It is possible to change the value judgment without touching it. The fact is that judgments about values depend on the description of the situation. The situation can be described in such a way as to "fit" it to the values. This is the essence of the change in perception.

Passive needs. Being activated, the latent need can become a passive need, since the future client, already aware of the potential benefits of the product, nevertheless still refrains from buying. When the consumer has a passive need, the purchase is impeded by uncertainty about future actions if the situation is confusing, contradictory or simply unclear. In fact, the consumer says: "Although I want a product (service) XYZ, I'm not going to buy it." Obstacles to buying can be:

1. The price that exceeds what the consumer is willing to pay - that is, the relative weight of the price is higher than the weight of perceived benefits.

2. False opinions, since the evaluation of benefits can be based on erroneous information.

3. True opinions about the product (service) and its performance characteristics may interfere with the purchase.

4. Doubt in statements about the product (service). Doubts can cause any statements, but especially in situations of high buyer involvement. A lot of doubts can arise, for example - "revolutionary improvements" in product functions, the quality of a multifunctional product, the improvement of some of the qualities of a product (service), obtained not at the expense of deterioration of its other qualities and the firm's ability to be competent in several product categories.

5. Social norms: consumers often act as if society is watching their purchases, even when the product (service) is not obvious to society. So, sales of cosmetics for men are still hampered by doubts about their social acceptability.

These barriers, perhaps, overcome, choosing the appropriate method of stimulating sales. Activation of hidden and passive needs is part of the necessary measures (costs) for entering any new product or service on the market. Conjugated with her difficulties can affect the process of diffusion (diffusion) of the novelty. For forecasting sales, key is also an assessment of the ability to uncover hidden and passive needs. In any case, "... it is necessary to understand what opportunities for development - non-obvious" points of growth "- are already available. It happens that the leaders carefully searched and found nothing. This is not surprising, because they are inside the situation and inside the "system", so they can not look at everything from the side "[8].

\section{References}

1. Borodai V.A. Torgovlja v sovremennom obshhestve: social'no-institucional'nyj analiz: monogr. Rostov-naDonu: IPO PI JuFU [Trade in modern society: socio-institutional analysis: monogr. Rostov-on-Don: IPO PI SFU]. 2008. 332 p. [in Russian].

2. Borodai V.A. Brend rabotodatelja kak DNK korporativnoj kul'tury servisnoj kompanii [Brand of the employer as DNA of corporate culture of service company] // Evropejskoe issledovanie [European Research], 2017. № 1 (24). P. 34 - 35.

3. Borodai V.A. Kraudrekruting kak kompetentnostnaja ocenka soiskatelej servisnoj kompanii [Crowd recruiting as the competence assessment of applicants service company] // Mezhdunarodnoe nauchnoe obozrenie [International Scientific Review]. 2017. № 1 (32). P. 46 - 47.

4. Bondarenko O.V., Borodai V.A. Social'nye kommunikacii v sfere rynochnogo obmena [Social communications in the sphere of market exchange] // Gumanitarnye i social'no-jekonomicheskie nauki [Humanitarian and socio-economic sciences], 2008. № 2. P. 156 - 158. [in Russian].

5. Borodai V.A. Innovacionnye tehnologii - strategicheskij podhod k korporativnym delovym poezdkam [Innovative technology - a strategic approach to corporate business travel] // Mezhdunarodnaja konferencija po sovremennym issledovanijam $\mathrm{v}$ oblasti nauki i tehniki: materialy I mezhdunarodnoj nauchnoprakticheskoj konferencii 31 janvarja 2017 goda, Berlin, Germanija: Nauchnaja obshhestvennaja organizacija «Professional'naja nauka» [International conference on modern researches in science and technology: materials of the I international research and practice conference January $31^{\text {th }}$, 2017, Berlin, Germany: Scientific public organization "Professional science"], 2017. $711 \mathrm{p}$.

6. Tret'jak A.A., Borodaj V.A. Korporativnaja kul'tura kak osnovnoj marker pri formirovanii brenda kompanii [Corporate culture as the main marker in the formation of the company's brand] // Jekonomika i socium [Economics and Society], 2016. № 2 (21). P. 1298 - 1301 [in Russian].

7. Borodai V.A. Jemocional'naja kompetentnost' - kognitivnye osobennosti [Emotional competence - cognitive features] // Jekonomika sovremennogo obshhestva: aktual'nye voprosy antikrizisnogo upravlenija. - Saratov: 
Akademija biznesa [Economics of modern society: topical issues of anti-crisis management. Saratov: Academy of Business], 2015. P. 28 - 31 [in Russian].

8. Borodaj V.A. Anagenez upravlenija innovacijami kak ideologema sovremennyh biznes processov servisnoj kompanii [Anagenesis management innovation as ideologeme modern business-processes service company] // Mezhdunarodnoe nauchnoe obozrenie [International Scientific Review], 2017. № 2 (33). P. 30 - 32. 